\title{
Household Perception and Preparednessagainst Flooding in Makurdi Town, Benue State, Nigeria.
}

\author{
Ahile, S.I ${ }^{1}$ andItyavyar, E.M ${ }^{2}$ \\ ${ }^{1 \& 2}$ Department of Geography, College of Advanced and Professional Studies, Makurdi, Nigeria.
}

\begin{abstract}
Thispaper assessed household perception and preparednessagainst floodingin Makurdi Town. Data was obtained from the field via questionnaire survey. A total of 236 respondents, mainly household heads (both male and female), drawn randomly from residents living in flood prone areas were sampled for the study. Descriptive statistics and Chi square test were used to analyse the data. Findings reveal that most residents (84.9\%) have experienced flooding in the area before and perceive that flood has increased in the last five years. Again, findings show that majority of the residents(48.7\%) are aware that they are staying in areas rated to be at high risk of flooding, but have remained in the area mainly because they don't have an alternative. Findings further show that households are not adequately prepared against flooding. The Chi square analysis showed no association between perception of flooding and household preparedness behaviour. The study recommends that a massive and rigorous awareness campaign should be carried out by the Government to educate people on the dangers of flood and the need to prepare in advance.
\end{abstract}

Keywords: Flooding, Perception, Risk, Household, Preparedness, Makurdi.

\section{Introduction}

Flood is a natural response of a river or stream or a mere drainage valley/channel that has too much water to cope with [1]. Flood occurs when water particularly from rainfall accumulates across an impermeable surface and cannot rapidly dissipate or evaporate [2].

The academic community is in agreement that flood is one of the most widespread, disastrous and frequent natural hazard of the world. Floods are triggered by factors which are partly or wholly climatological in nature [3], but human activity often escalate the frequency and severityof the floods. Floods can affect the social, economic and political wellbeing of a people.

In Makurdi town, flooding has almost become an annual event leading to loss and destruction of properties worth millions of naira [4]. In 1996, 2000, 2005, 2007 and 2008, flooding has occurred in different parts of the town [5]. The most recent is the 2012 floods which is unprecedented, was caused by the failure of a dam in Cameroon.

Meteorologists predict heavier rainstorms with the prospects of more flood challenges. [6] predictthat in the next few years, flooding is likely to become more common and more intense in many areas especially in low-lying sites or in zones that are currently experiencing high rainfall. This is a wake-up for all stakeholders to take steps towards checking future floods.

Consequently, it has become increasingly important to make attempts to understand people's perception of floods and other natural hazards. This is because the knowledge of the public's risk perception is considered a crucial aspect in modern flood risk management as it steers the development of effective flood mitigation strategies [7]. Specifically, understanding people's perception of natural hazards may likely provide information about their willingness or unwillingness to prepare for future occurrence [8]. For instance, [9] noted that the devastation caused by urban floods especially on households, in most cases, is usually a reflection of their lack of preparedness.

Previous studies on flood incidence in Makurdi town have focused on assessment of flood damage [10]; an examination of rainfall pattern and its implication on flood frequency [11], a comparative analysis of the effects of annual flooding on the maternal health of women floodplain and non-floodplain dwellers [12] and residents coping measures in flood prone areas [13]. [4],looked at social impact and people's perception of flooding. Studies on flood risk perception especially in northern Nigeria is still scanty. In the face of increased frequency of flood in the region, more research effort is needed to provide insight to policy makers. This paper extends the literature. The paper assesses household perception and preparedness against flooding in Makurdi town. The study will attempt to provide answers to the following questions: What is the perception of household to the risk of flooding in Makurdi town? What is the level of preparedness of households against future flood occurrences? Is the flood preparedness behaviour of households' dependent of their perception? To address the last question, a hypothesis is formulated as follows:

Ho: Household preparedness against flooding is independent of their perception. 


\section{Methodology}

The study utilized both primary and secondary data. Secondary data was sourced from the literature, while primary data was sourced using a structured questionnaire which was administered to 236 household heads (both male and female), randomly selected from people living in flood prone areas: Gyado Villa, Wurukum, Idye, Logo, Wadata and Akpehe. The sample size was drawn based on similar works carried out in the study area [14]. The questionnaire was designed to elicit information on socio- demographic characteristics of respondents, their understanding of what flood is, their past experience with flood, perception about the frequency of flood occurrence, assessment of their area's risk to flooding, and reasons for their continued stay in flood prone areas. The instrument was also used to get information on flood preparedness measures practiced by households. To determine the level of household's preparedness against flood events, respondents were asked to answer either YES or NO to a list of seven likely actions (to indicate whether they adopted the preparedness measure or not) adopted from [15] and [16]. The study estimates that if a respondent answers YES to four of the seven preparedness actions, then such a person is deemed to be prepared against flood. If otherwise, the person is not prepared. Chi square analysis was used to determine the relationship between perception of flooding and household preparedness behaviour. Other results were presented using descriptive statistics.

\section{Description of the Study Area}

Makurdi lies between latitudes $7^{0} 37^{\prime}$ and $7^{0} 47^{\prime}$ North and longitude $8^{0} 27^{\prime}$ and $8^{0} 40^{\prime}$ East(see figure 1 below).Makurdi is drained by the River Benue which bisects the town into two parts-north and south banks. . Other minor rivers that drain the town, and in turn empty their waters in the River Benue includes: Rivers Idye, Genebe, Urudu, Kpege and Kereke. . Due to the general low relief of Makurdi, sizeable portions of the area is waterlogged and flooded during heavy rainstorm. The climate is hot and humid which corresponds with Koppen's'Aw' climate classification. Temperatures are generally high throughout the year due to the

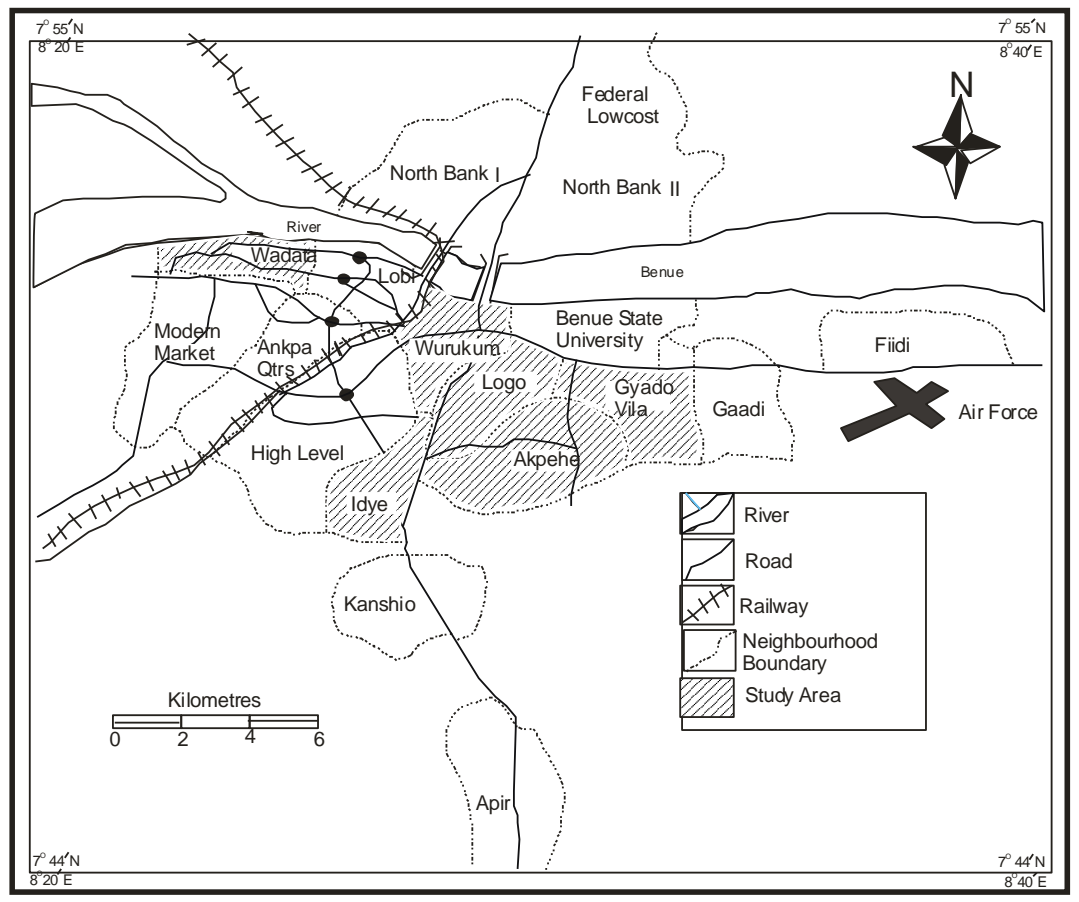

Fig. 1. Map of Makurdi Town Showing Flood Prone Areas

Source: Ministry of Land and Survey, Makurdi.

constancy of insolation with the maximum of $33^{\circ} \mathrm{C}$ and a mean minimum of $22.5^{\circ} \mathrm{C}$ with annual range of $10.5^{\circ} \mathrm{C}[17]$. Temperatures may occasionally climb to $37^{\circ} \mathrm{C}$ in some days in March and April [18].Humidity is high all year round. The rainfall of the area is highly seasonal, coming inform of intense, violent, convectional showers of short duration. The geology of Makurdi town is of cretaceous and consists of fluvio-deltaic sediments with well-bedded sandstones which are of hydrogeological significance in terms of groundwater yield and exploitation [19]. 


\section{Results and Discussion}

\subsection{Socio- demographic Characteristics of Respondents}

The results of findings on the vital statistics of the respondents reveals that $70.8 \%$ are males while $29.2 \%$ are female. $15.3 \%$ are below the 31 years, $27.2 \%$ are between the ages of $31-40,41.5 \%$ are between the ages of $41-50,9.3 \%$ are between the ages of $51-60$, while $6.7 \%$ age over 60 years. Results also show that $8.9 \%$ have no formal education, $6.8 \%$ have primary education, $26.2 \%$ have secondary education, while $58.1 \%$ have tertiary education. The results further reveal that $35.2 \%$ are civil servants, $11.0 \%$ are farmers, $7.2 \%$ are artisans, $20.3 \%$ are traders, $10.3 \%$ are unemployed, while $16.0 \%$ have retired. The findings finally reveal that $41.1 \%$ are landlords while 58.9 are tenants.

\subsection{Perception of Flooding Makurdi Town}

Risk perception refers to the intuitive risk judgement of individuals and social groups[20]. It involves the examination of people's awareness, emotions, and behaviour with respect to hazards(flood).

The knowledge people have of a particular hazard should determine their perception of the hazard. Table 1,shows respondents view of what flood means. The findings show that respondents generally demonstrated sound knowledge of flood $.30 .1 \%$ of the respondents understand flood to mean a natural hazard which causes a lot of destruction; $28.8 \%$ of them said it is a high flow of water which oversteps the natural channel provided for runoff, $17.8 \%$ simply understood flood to mean excess water found on a normally dry land, $15.3 \%$ said flood is a natural response of a river or stream to excess water, while $6.4 \%$ of the respondents simply understood flood to be an act of God. $1.7 \%$ of the respondent said they were not sure. It is expected that the respondents comprising $30.1 \%$, should have a higher perception of risk to flooding compared with the other respondents. This is because they associate floods with destruction.

Table 1.Knowledge/Understandingof Flood.

\begin{tabular}{|l|l|l|l|}
\hline S/No. & & $\mathbf{F}$ & $(\%)$ \\
\hline 1. & A natural response of a river/stream to excess water & 36 & 15.3 \\
\hline 2. & Excess water found on a normally dry land & 42 & 17.8 \\
\hline 3. & $\begin{array}{l}\text { A relatively high flow which oversteps } \\
\text { the natural channel provided for runoff }\end{array}$ & 68 & 28.8 \\
\hline 4. & A natural hazard which causes a lot of destruction & 71 & 30.1 \\
\hline 5. & An act of God & 19 & 8.1 \\
\hline & Total & $\mathbf{2 3 6}$ & $\mathbf{1 0 0}$ \\
\hline
\end{tabular}

The study also sought to find out if respondents have experienced flood in the area before. From Table 2 , the results reveal that $84.3 \%$ responded to the affirmative while $14.4 \%$ said they have not. $1.3 \%$ of them didn't respond to question. This indicates that since the majority of the respondents have experienced flooding before, they should have a high perception of risk to flooding. Previous research has also shown that past experience is an important factor influencing people's perception of hazards[21;22].

Table 2.Past Experiencewith Floods.

\begin{tabular}{|l|l|l|l|}
\hline \multicolumn{1}{|c|}{ S/No. } & \multicolumn{1}{|c|}{ Response } & F & $(\boldsymbol{\%})$ \\
\hline 1. & Yes & 199 & 84.9 \\
\hline 2. & No & 34 & 14.4 \\
\hline 3 & Undecided & 3 & 1.3 \\
\hline & Total & $\mathbf{2 3 6}$ & $\mathbf{1 0 0}$ \\
\hline
\end{tabular}

Source: Authors Fieldwork,2014

Respondentswere asked to air their view about the frequency of floodoccurrence in the study area in the last five years. Table 3, is a summary of their response. Findings reveal that $61.9 \%$ of the respondents observed that flood events have increased, $34.7 \%$ observed that flood events have decreased, while $3.4 \%$ were not sure. The observation by the majority(61.9\%) of the respondents is consistent with findings from studies carried out by [23] and [24] in Uyo and Jalingo respectively. [13], also believe that floods are globally becoming more frequent in response to climate change.

Table 3.Perception aboutthe Frequencyof Flood Occurrence.

\begin{tabular}{|l|l|l|l|}
\hline S/No. & Response & F & $(\%)$ \\
\hline $\mathbf{1 .}$ & Flood has increased & 146 & 61.9 \\
\hline $\mathbf{2 .}$ & Flood has decreased & 82 & 34.7 \\
\hline $\mathbf{3 .}$ & Not sure & 8 & 3.4 \\
\hline & Total & $\mathbf{2 3 6}$ & $\mathbf{1 0 0}$ \\
\hline \multicolumn{3}{|c|}{ Source: Authors Fieldwork,2014 }
\end{tabular}


A further analysis was done to get the perception of the respondents about the frequency of flood occurrences in the last five years based on their location. From Table 4, the results show that $86.7 \%$ of the respondents from Gyado Villa and $82.1 \%$ from Wadata areas of the town observed that flood has increased over the last five years. These areas are lying close to the River Benue and were severely hit by the 2012 floods. This is likely to have informed their response. This indicates that people's location and their previous experience with flood can heighten their perception.Conversely, $77.5 \%$ and $64.9 \%$ of respondents from Akpehe and Logo areas respectively observed that flood has decreased.These areas though prone to flood were not seriously affected by the recent floods.

Table4. Perception aboutthe Frequencyof Flood Occurrenceby Location

\begin{tabular}{|c|c|c|c|c|}
\hline & \multicolumn{2}{|c|}{ RESPONSE } & \multirow{2}{*}{ Not Sure } & \multirow[b]{2}{*}{ Total } \\
\hline Location & Flood has increased & Flood has decreased & & \\
\hline \multirow{2}{*}{$\begin{array}{r}\text { Gyado Villa F } \\
\%\end{array}$} & 26 & 3 & & 30 \\
\hline & 86.7 & 10.0 & 3.3 & $100 \%$ \\
\hline \multirow{2}{*}{$\begin{array}{ll}\text { Logo 1 } & \text { F } \\
& \%\end{array}$} & 13 & 24 & 0 & 34 \\
\hline & 35.1 & 64.9 & 0 & $100 \%$ \\
\hline \multirow{2}{*}{$\begin{array}{ll}\text { Wurukum } & \mathrm{F} \\
& \%\end{array}$} & 33 & 9 & 3 & 45 \\
\hline & 73.3 & 20.0 & 6.7 & $100 \%$ \\
\hline \multirow{2}{*}{$\begin{array}{ll}\text { Idye } & \mathrm{F} \\
& \%\end{array}$} & 34 & 9 & 2 & 45 \\
\hline & 75.6 & 20.0 & 4.4 & $100 \%$ \\
\hline \multirow[t]{2}{*}{ Akpehe } & 8 & 31 & 1 & 40 \\
\hline & 20.0 & 77.5 & 2.5 & $100 \%$ \\
\hline \multirow[t]{2}{*}{ Wadata } & 32 & 6 & 1 & 39 \\
\hline & 82.1 & 15.3 & 2.6 & $100 \%$ \\
\hline Total & 146 & 82 & 8 & 236 \\
\hline$\%$ & 61.9 & 34.7 & 3.4 & $100 \%$ \\
\hline
\end{tabular}

Source: Authors Fieldwork, 2014

The study also sought to find outrespondents view about their area's level of risk to flooding. From Table 5, the findings showthat $48.7 \%$ regard their area to be at high risk; $29.7 \%$ said their area was at medium risk,5.5\% said their area wasn't at risk, while $1.3 \%$ did not respond.

Table 5.Assessmentof Area's Riskto Flooding.

\begin{tabular}{|l|l|l|l|}
\hline S/No. & Response & F & $\mathbf{( \% )}$ \\
\hline $\mathbf{1 .}$ & High risk & 115 & 48.7 \\
\hline $\mathbf{2 .}$ & Medium risk & 70 & 29.7 \\
\hline $\mathbf{3 .}$ & Low risk & 35 & 14.8 \\
\hline $\mathbf{4 .}$ & No risk & 13 & 5.5 \\
\hline $\mathbf{5 .}$ & Undecided & 3 & 1.3 \\
\hline & Total & $\mathbf{2 3 6}$ & $\mathbf{1 0 0}$ \\
\hline
\end{tabular}

Source: Authors Fieldwork,2014

When asked why they were still staying in the area despite the awareness of their area's risk to flooding, different reasons were given. From Table 6, findings reveal that $32.6 \%$ of the respondents said it was because they don't have an alternative. This isbecause the property they were occupying belonged to them and they were not willing to move into rented apartments elsewhere. $18.6 \%$ indicated that the low cost of land and housing was responsible for their continued stay, $12.7 \%$ said it was because they have stayed in the area for a long time. Also, $11.9 \%$ are still staying in the area to maintain ties with family and friends, $10.6 \%$ cited proximity of the area to their work or business location as their reason,7.6\% said it's because the area is not crowded, while $5.9 \%$ did not respond to the question.

Table 6.ReasonsforContinued Stayin Flood Prone Areas.

\begin{tabular}{|l|l|l|l|}
\hline S/No. & Reasons & $\mathbf{F}$ & $\mathbf{( \% )}$ \\
\hline $\mathbf{1 .}$ & Low cost of land and housing & 44 & 18.6 \\
\hline $\mathbf{2 .}$ & Area is not crowded & 18 & 7.6 \\
\hline $\mathbf{3 .}$ & Stayed in the area for a long time & 30 & 12.7 \\
\hline $\mathbf{4 .}$ & Proximity to work or business location & 25 & 10.6 \\
\hline $\mathbf{5 .}$ & To maintain ties with family and friends & 28 & 11.9 \\
\hline $\mathbf{6 .}$ & Don't have an alternative & 77 & 32.6 \\
\hline $\mathbf{7 .}$ & Undecided & 14 & 5.9 \\
\hline & Total & $\mathbf{2 3 6}$ & $\mathbf{1 0 0 \%}$ \\
\hline
\end{tabular}

Source: Authors Fieldwork,2014

The people were also asked if they had any fear or were worried about future flood occurrence. From Table 7,findings reveal that $77.1 \%$ responded to the affirmative, $19.1 \%$ said they did not, while $3.8 \%$ did not respond to the question. The fear or worry expressed by people concerning a hazard is likely to disappear with time if the hazard no longer occurs [8]. 
Table 7. Expression of Worryor FearAboutFuture Flood Occurrence.

\begin{tabular}{|l|l|l|l|}
\hline S/No. & Response & F & $\mathbf{( \% )}$ \\
\hline $\mathbf{1 .}$ & Yes & 182 & 77.1 \\
\hline $\mathbf{2 .}$ & No & 45 & 19.1 \\
\hline 3. & Undecided & 9 & 3.8 \\
\hline & Total & $\mathbf{2 3 6}$ & $\mathbf{1 0 0 \%}$ \\
\hline
\end{tabular}

Source: Authors Fieldwork,2014

\subsection{Household's Level of Flood Preparedness}

Flood preparedness is about putting in place a set of appropriate arrangements in advance for an effective response to floods[15]. Preparedness is regarded as an important aspect of disaster management.

Table 8.Household Levelof Preparednessagainst Flooding in Makurdi.

\begin{tabular}{|l|l|l|}
\hline \multirow{2}{*}{ Preparedness measure } & \multicolumn{2}{l|}{ Level of preparedness } \\
\cline { 2 - 3 } Yes & No \\
\hline Do you have a medical kit for disaster emergency? & $32(13.6 \%)$ & $204(86.4 \%)$ \\
\hline $\begin{array}{l}\text { Do you have a separate savings account for } \\
\text { flood or disaster emergency? }\end{array}$ & $20(8.5 \%)$ & $216(91.5 \%)$ \\
\hline $\begin{array}{l}\text { Do you keep disaster emergency phone numbers } \\
\text { e.g. SEMA, NEMA? }\end{array}$ & $33(14.0 \%)$ & $203(86.0 \%)$ \\
\hline $\begin{array}{l}\text { Do you have a contingency plan for relocation } \\
\text { should flood occur? }\end{array}$ & $103(43.6 \%)$ & $133(56.4 \%)$ \\
\hline Do you frequently evacuate sand from blocked drainages? & $162(68.6 \%)$ & $74(31.4 \%)$ \\
\hline Are you aware of any flood warning system? & $108(45.8 \%)$ & $128(54.2 \%)$ \\
\hline Do you frequently educate your household about flood disaster? & $140(59.3 \%)$ & $96(40.7 \%)$ \\
\hline
\end{tabular}

Source: Authors Fieldwork, 2014.

An assessment of household level of preparedness against flood was undertaking. From table 8, the findings show that the percentage response for those that said they did not adopt five preparedness measures $(86.4 \%, 91.5 \%, 86.0 \%, 56.4 \%$, and $54.2 \%)$ is greater than those that said they adopted $\operatorname{them}(13.6 \%, 8.5 \%$, $14.0 \%, 43.6 \%$, and $45.8 \%$ ). The mean percentage response for those that said they didn't adopt the measures is $74.9 \%$ as against $25.1 \%$ for those that said theydid adopt the measures. For the remaining two measures, the percentage response for those that said they did adopt the measures $(68.6 \%$, and $59.3 \%)$ is greater than those that indicated they didn't adopt them(31.4\% and 40.7\%). The mean percentage response for those that said they did adopt the measures is $63.9 \%$ as against $36.1 \%$ for that indicated that they didn't. Based on these findings (and method employed), the study concludes that households are not prepared against flooding.

To establish whether there was any relationship between perception of flooding and household preparedness behaviour, the hypothesis that household preparedness against flooding is independent of their perception was tested at 5\% level of significance using the Chi square. From Table 9, the results reveal that the $\mathrm{P}$ - value (0.207) is greater than 0.05 . We therefore accept the null hypothesis. This means that perception (on frequency of flood occurrence)does not influence household preparedness behaviour(willingness to get medical kits for disaster emergencies). The implication is that whether residents perceive that flood has increased, remained the same or decreased in the last five years, it has not influenced their willingness or unwillingnessto get medical kits for disaster emergencies. A conclusion is drawn that the preparedness behaviour of households in Makurdi town against flooding is influenced by factors other than their perception.

Table 9.Relationship between Perceptionof Flooding and Household PreparednessBehaviour.

\begin{tabular}{|l|l|l|l|}
\hline & Value & Df & Asymp. Sig. (2 sided) \\
\hline Pearson chi-square & $\mathbf{5 . 8 9 3 a}$ & 4 & .207 \\
\hline Likelihood Ratio & 5.280 & 4 & .260 \\
\hline Linear by linear association & .941 & 1 & .332 \\
\hline N of valid cases & 236 & & \\
\hline
\end{tabular}

Tested at 5\% level of significance; Source: SPSS

\section{Conclusion}

Flood perception is expected to give insight about people's willingness to prepare against flooding. The study reveals that the people generally demonstrate a sound understanding of flood and are aware that they are staying in areas rated to be at high risk of flooding. Despite this, it has been observed that households are not adequately prepared against flooding. The implication is that residents of Makurdi town, especially those living in flood prone areas are likely to be seriously affected should another flood occur. The findings of this study should help policy makers formulate policies that will be geared towards sustainable flood management. This should include public education and campaign on the dangers of flood and the need for people to prepare in advance. Community efforts towards flood control and mitigation should be encouraged. 
Based on the revelation that the flood perception of residents in Makurdi town does not influence their preparedness, it is suggested that further studies can investigate the factors that influence resident's preparedness against flooding.

\section{References}

[1]. K.A. Aderogba,Qualitative Studies of Recent Floods and Sustainable Growth and Development of Cities and Towns in Nigeria. International Journal of Academic Research in Economics and Management Sciences,1(3),2012,200-216.

[2]. K. Efobi, andC. Anierobi, Hazard Reduction Strategies for Flood Vulnerable Communities in Anambra State, Nigeria: Towards Sustainability. International Affairs and Global Strategy,vol.16, 2013.

[3]. J.O. Ayoade, Tropical hydrology and water resources(MacMilan Publishers,Ibadan,1988).

[4]. M. Ocheri, andE. Okele, Social Impact and People's Perception of Flooding in Makurdi Town, Nigeria. Special Publication of the Nigerian Association of Hydrological Sciences, 2012.

[5]. Federal Ministry of Environment/UNDP. Automated web-based Early Warning System (EWS) Launched in Abuja,2012.

[6]. D.N. Olayinka, P.C Nwilo, andA.E.Adzandeh, From Catchment to Reach: Predictive Modelling of Flood in Nigeria, Environment for Sustainability, 2013.

[7]. W. Kellens, , R. Zaalberg, T. Neutens, W. Vannenville, andP.D. Maeyer, An Analysis of the Public Perception of Flood Risk on the Belgian Coast. Risk Analysis,31(7),2011,408-414.

[8]. A.J. Prelog, andL.M. Miller, Perception of Disaster Risk andVulnerability in Rural Texas. Journal ofRural Social Sciences,28(3),2013.

[9]. M.L. Ojigi, F.I. Abdulkadir, andM.O. Aderogu, Geospatial Mapping and Analysis of the 2012 Flood Disaster in Central Parts of Nigeria. $8^{\text {th }}$ National Symposium, Damma, Saudi Arabia, 2013.

[10]. P. Ali, Flood Damage Assessment in Makurdi Town, Unpublished M.Sc Project, Department of Geography, Benue State University,Makurdi,2005.

[11]. E.T. Ologunorisa, andT. Tor, The Changing Rainfall Pattern and its Implication for Flood Frequency in Makurdi, Northern Nigeria. Journal of Applied Sciences and Environmental Management, 10(3),2006, 97-102.

[12]. I.D. Mngutyo, andJ. Ogwuche, Comparative Analysis of the Effect of Annual Flooding on the Maternal Health of Women Floodplain and non- Floodplain Dwellers in Makurdi Urban Area, Benue State, Nigeria. Herald Journal of Geography and Regional Planning,2(3), 2013,116-121.

[13]. T. Shabu, andT.E. Tyonum, Residents Coping Measures in Flood Prone Areas of Makurdi Town, Benue State. Applied Ecology and Environmental Science, 1(6), 2013, 120-125.

[14]. A, Akpa, Knowledge creation process: concepts and application in social research (Makurdi: Aboki Publishers,2011).

[15]. M.N. Ezemonye, and C.N. Emeribe, Flooding and Household Preparedness in Benin City, Nigeria. Mediterranean Journal of Social Sciences,5(1),2014,547-553

[16]. W. Adiyoso, Factors Influencing Flood Preparedness Behaviour: Case Study of Ayutthaya Community Thailand. Workshop of JSPS International Training Programme, Ritsumeikan University, Japan,2012.

[17]. M. Ocheri, Analysis of Water Consumption Pattern in Makurdi Metropolis. Journal of Geography andDevelopment,1(1),2006,7183.

[18]. S.A. Iorkua, A Study of Inter- Relationship among Gully Elements in North Bank, Makurdi. Journal of Geography and Development, 1(1),2006,32-51

[19]. C.A. Kogbe, A. Torkshi, D. Osijuk, andD.EWozney, Geology of Makurdi in the Middle Benue Valley, Nigeria. Occasional Publication of the Department of Geology, Ahmadu Bello University Zaria,1978.

[20]. P. Slovic, Perception of Risk. Science,236(4799),1987,280- 285.

[21] N.D. Weinsten, Effects of Personal Experience on Self- Protective Behaviour. Psychological Bulletin,105,1989,31-50.

[22]. D.Aboagye, T. Dari, and J. Koomson, Risk Perception and Disaster Management in the Savannah Region of Ghana. International Journal of Humanities and Social Science, 3(3),2013.

[23]. C.E. Udosen, Rainfall Trends in Uyo - Akwalbom State and its Implication on Urban Flooding. Journal of Engineering and Applied Sciences, 7(1), 2012,79-85.

[24]. E.D. Oruonye, An Assessment of Flood Risk Perception and Response in Jalingo Metropolis, Taraba State, Nigeria. International Journal of Forest, Soil and Erosion,3(4), 2013, 113-117. 